\title{
Languages at work in the Basque Autonomous Community
}

\author{
Karin van der Worp \\ University of the Basque Country, UPV/EHU \\ karin.vanderworp@ehu.eus
}

\begin{abstract}
In the Basque Autonomous Community, the presence of the local minority language Basque has gradually increased in the workplace due to recent language policies, although the local majority language Spanish is still clearly prevalent. At the same time, in consequence of internationalization, English has also gained in importance as a lingua franca for international work-related activities. This paper analyses the perceptions of professionals and future professionals regarding this "glocal" linguistic repertoire in the workplace of the Basque Autonomous Community.
\end{abstract}

Keywords: multilingualism, workplace, global language, minority language, majority language 


\section{Introduction}

The Basque Autonomous Community (BAC) is a bilingual region in the north of Spain, where the minority language Basque and the majority language Spanish coexist. Spanish is the prevalent language in society and the Basque Government has undertaken strong efforts at all levels of society to increase the knowledge and use of Basque, in education, public administration and private companies. The results are generally positive, as the knowledge and use of Basque has incremented significantly over time.

At the same time, as in many other regions in Europe, in the BAC the influence of foreign languages is also increasing at all levels of society. English in particular has become an important third language in the region. Due to tourism, promotion of the prestige of English, and globalization, English has gained in importance in Basque society.

The presence of the minority and majority language, on the one hand, and the increasing presence of the global language English, on the other, have led to an interesting situation of "glocalisation", as Robertson (1992) calls it. This "glocal" multilingualism has naturally appeared particularly in workplaces in the BAC in recent decades. Companies that decided to locate in the BAC first had to deal with the local languages in the area to successfully run their business. However, over recent decades, several factors have created a need for additional languages, such as the internationalization of companies to countries abroad, selling and buying on the international market, the incorporation of international staff into the local workforce and new communication technologies favouring international communication. Nowadays, companies have to attend to linguistic needs in both a local and a global environment, which has led to multilingual workplaces.

This study aims to grasp the perceptions of professionals and future professionals regarding this complex linguistic situation where both local and global languages are used by the companies in the BAC. The paper draws on a selection of qualitative and quantitative data collected from professionals and future professionals in the BAC to shed light on how they perceive the languages in the workplace of the BAC, in terms of competences, importance and use. In doing so, the study aims to provide an in-depth understanding of the multilingual situation in companies in the BAC that can serve as a basis for drafting recommendations for improvement in the area.

First of all, some of the theories that underpin this study will be briefly explained. Then, the specific context of the BAC, particularly the sociolinguistic context and the workplace, will be discussed in detail. And finally the key results will be presented and the findings discussed. 


\section{Theoretical framework}

First of all, it is important to specify what is meant by the term multilingualism, since many different definitions are available in the literature (Kemp, 2009). The European Commission (2007) proposes the following useful definition: "Multilingualism is understood as the ability of societies, institutions, groups and individuals to engage, on a regular basis, with more than one language in their day-to-day lives" (p. 6). This definition is useful for two main reasons. First, it refers to the capacity to engage with more than one language, in other words, to carry out activities not only in one language, but in two or more. It makes no comparison with native-like competences, which is an important aspect of the way multilingualism is interpreted in this study, as will be explained below. Second, the division between individual and social multilingualism, as proposed by Fishman in 1980, is accounted for by this definition, which explains multilingualism as both an individual phenomenon and a societal phenomenon (see also Cenoz \& Gorter, 2012; Edwards, 1995).

Franceschini (2009) adds that" multilingualism is a product of the fundamental human ability to communicate in a number of languages. Operational distinctions may then be drawn between social, institutional, discursive and individual multilingualism" (p. 34). This definition makes the three common distinctions between social, institutional and individual multilingualism, and adds a less common fourth type (2009): discursive multilingualism. However, professional multilingualism is not included as an operational distinction. We argue that professional multilingualism as a fifth operational distinction would be useful, given the fact that multilingualism in the workplace has more specific characteristics than other types of multilingualism. Carrying out professional tasks in foreign languages can be different from and more complicated than using language in daily life. Furthermore, companies often use multilingualism in the workplace to obtain an economic benefit. Of the various languages available, companies choose the most communicatively efficient working language that will provide the most efficient benefit (Alarcón, 2005). As a consequence, in professional settings, language diversity is usually seen as a barrier to economic efficiency (Solé et alii, 2005). All this needs to be considered when analyzing such a specific operational distinction of multilingualism: professional multilingualism.

Now that we have clarified what we understand by the term multilingualism, we need to elaborate on the framework within which we interpret this term. This paper is based on the idea that multilingualism is not just a bunch of separate languages. Instead, we believe that studies on multilingualism should consider that speakers have a complex repertoire of interrelated languages which they 
use in specific contexts. This idea comes from the "Focus on Multilingualism" proposed by Cenoz and Gorter (2011a, 2011b \& 2014), an approach that provides insights into the main principles of multilingualism in educational settings. It distinguishes three interrelated dimensions: the multilingual speaker, the whole linguistic repertoire and the social context.

The multilingual speaker, who has a fluid communicative competence in more than one language, is regarded as the centre of multilingualism. The multilingual speaker is not a sum of several monolinguals and should not be compared to native speakers, but should be considered a true multilingual speaker instead. The linguistic repertoire describes the different resources the speaker has available for learning and using languages, taking into account that principles and strategies acquired in one language can be usefully transferred to another language. The social context should also be considered, since language practices always take place in a social context. The influence of this context should therefore be taken into account if multilingualism is to be understood.

The Focus on Multilingualism, which was originally applied in educational contexts, could also be helpful to understand multilingualism in the workplace. For the professional context, the three interrelated dimensions are the following. The first dimension is the multilingual professional with several language and cultural competences and language attitudes. The second dimension is the professional linguistic repertoire, which includes a variety of language practices and the language learning experiences of the staff. The third dimension is the context, since the company is embedded in a context that influences the use of languages. In the case of the workplace the most direct contextual factors that influence multilingualism are the economy, culture, language education and language policy (for a more extensive explanation of the Focus on Multilingualism in the workplace, see Van der Worp et alii 2017). The influence of the context on professional discourse is also underlined by Gunnarsson (2009, 2013 \& 2014), who specifies the contextual influencing factors in terms of "societal frameworks": technological-economical, legal-political, socio-cultural and linguistic.

The expression multilingual professionals needs to be defined in terms of the kind of professionals that a study aims to analyze. Gunnarsson (2013) distinguishes two broad categories of multilingual professionals. At one end of the scale, there are low paid migrants who work in entry-level jobs and often need to use a language that they do not fully master at work. At the other end of the scale, there are the well educated professionals who can move between jobs and countries to improve their work life opportunities and are often proficient in several languages. The professionals of this second category can be working 
either in their home country or abroad. This paper focuses especially on this second category, the "bilingual professionals" (Day \& Wagner, 2007), who are well educated and proficient in several languages.

After this short description of the theoretical framework of this study, I shall now move on to explain the context of the study, the Basque Autonomous Community.

\section{The context of the Basque Autonomous Community}

In this section, the context of the Basque Autonomous Community (BAC) will be explained. First of all, some basic background information about the BAC will be provided, followed by some data about the economy and the recent internationalization, and, finally, the linguistic situation.

\section{The Basque Autonomous Community}

The Basque Autonomous Community (BAC) is part of the historical Basque Country, a bilingual region spanning two countries: France and Spain. The part in France is known as Iparralde ("the northern region"), whereas the part in Spain is divided into the Autonomous Community of Navarre and the Autonomous Community of the Basque Country. The linguistic situations of the different administrative areas within the Basque Country are completely different, due to different statuses of the minority language and differing numbers of bilingual speakers in the areas. Even within the areas, there are considerable differences between the various provinces. Within the Basque Country linguistic realities are highly diverse, so studies on any specific area should bear in mind the specific local context. In the present study, the focus is on the Basque Autonomous Community where both Spanish and Basque are officially recognized languages. The BAC has a population of almost 2.2 million inhabitants (EUSTAT, 2017a). The population is spread over three provinces, with Bizkaia being the most densely populated, followed by Gipuzkoa and Araba, respectively.

\section{Economy of the Basque Autonomous Community and internationalization}

In terms of economy, the BAC is one of the main industrial areas in Spain. After services (69.1\% of GDP), industry (24.1\% of GDP) is the second most important area for this region, followed by construction $(5.9 \%)$ and agriculture and fishing (0.8\% GDP) (EUSTAT, 2018). 
Within the industrial sector, export from the Basque Autonomous Community has steadily increased over time. The five countries most of the export goes to are, in order of importance, Germany and France (over 30\% of all the export), United States, United Kingdom and Italy (19\% of all the export) (EUSTAT, 2017b). And for import, the data are rather similar since most is from Germany, France, United Kingdom, China and Italy (EUSTAT, 2017c).

In order to become more competitive on the international market, the Basque Government has recently developed a strong policy for internationalizing small and medium enterprises. The Department of Economic Development and Competitiveness of the Basque Government defines the main aim of this internationalization strategy as follows:

Crear las condiciones necesarias para conseguir una mayor internacionalización de las empresas vascas como elemento clave de competitividad para afrontar ese proceso de globalización de la economía mundial y aprovechar las oportunidades derivadas del mismo.

[To create the necessary conditions to achieve a greater internationalization of the Basque companies as a key element for competitiveness to face the globalization process of the world economy and take advantage of the opportunities originated.]

(Basque Government, 2015)

Theyaremainlyworkingin threeareas: exterior promotion, internationalization and cooperation, and talent for internationalization. However, the role of foreign languages is apparently not a factor that is taken into account in this international strategy.

This lack of attention to foreign languages for internationalization is in contrast with the language policies undertaken by the Basque Government to promote Basque alongside Spanish. In the next section, the local linguistic situation will be described.

\section{Languages in the Basque Autonomous Community}

The local languages of the BAC are the minority language Basque and the majority language Spanish. As mentioned above, the extent to which Basque is known and used in the various parts of the Basque Country is quite different. The Basque Government (2016) provides the following data about the linguistic situation in the BAC. A total of $33.9 \%$ of the population of 16 years and older are speakers of Basque, 19.1\% are passive speakers of Basque (they understand Basque but 
cannot speak it) and 47\%, the majority, are monolingual Spanish speakers. As already mentioned, among the three provinces within the BAC, differences are noticeable. Whereas in Gipuzkoa more than half of the inhabitants are speakers of Basque (50.6\%), in Bizkaia this percentage is only $27.6 \%$. In Araba it is even lower $(19.2 \%)$.

It should be pointed out, though, that over the last 25 years there has been a positive development in the number of Basque speakers. Comparing data from 2016 with data from 1991 shows an increase of almost $10 \%$ over the last 25 years (212,000 more Basque speakers). The percentage of Basque speakers in the total population has increased from $24.1 \%$ to $33.9 \%$. It has to be underlined that the increase in Basque speakers is mostly noticeable in the younger population.

Following the same trend, the number of passive Basque speakers has also increased over that same period by almost $11 \%$, increasing from $8.5 \%$ of the population in 1991 to $19.1 \%$ of the population in 2016 . On the other hand, the numbers of monolingual Spanish speakers have decreased by $12 \%$, from $59.2 \%$ of the population in 1991 to $47 \%$ in 2016 , the first time that monolingual Spanish speakers are less than half of the population. ${ }^{1}$

However, despite of the fact that Basque speakers are bilingual, they do not all feel equally comfortable using Basque and Spanish. A total of $28.6 \%$ of the Basque speakers feel more comfortable expressing themselves in Basque than in Spanish (bilinguals with a predominance of Basque). This group consists mostly of elderly people. The so-called balanced bilinguals, the ones who consider they express themselves equally fluently in Basque and Spanish, are 29.3\% of the Basque-speaking population. This group consists mainly of the population between 25 and 64 years old. Still, the bilinguals who feel more fluent in Spanish are the biggest group, consisting of $44 \%$ of the Basque speakers. The data show that it is mainly the younger population who feel more fluent in Spanish than in Basque. Compared to 25 years ago, when the number of speakers with predominance in Basque and the ones with predominance in Spanish were almost equal, nowadays Spanish predominance outnumbers Basque predominance.

The data above all refer to knowledge of Basque, but the Basque Government (2016) has also gathered data about the actual use of Basque. Most of the same population of 16 years or older in the BAC almost always uses Spanish (69.4\%). Only $20.5 \%$ of the population uses Basque intensively (that is to say, to the same extent or more than Spanish). A total of $10.1 \%$ use Basque, but less than Spanish. We can see that there is a considerable gap between knowledge of Basque on the one hand, and the actual use of the language on the other. This is one of the main

1 Compared to the last sociolinguistic survey (Basque Government, 2011). 
concerns of the Basque Government and an important focus in their strategies to support the use of Basque in society.

The situation of use and knowledge of the local official languages is complex but adding other languages makes it even more complex. As in Europe as a whole, cosmopolitanism and international collaboration have made English fundamental to any work on an international or European level (EF, 2017). In this regard, according to EF data (2017), English-language skills in Spain are on the average-to-medium level, slightly above the European average. However, Spain is rather low on the list (21 $1^{\text {st }}$ place out of 27$)$ compared to other countries.

However, like Basque in the different areas of the Basque Country, the command of English is different in the different communities in Spain. For this reason, although general information on English competence in Spain as a whole can serve as a rough indicator, it cannot account for the specific situation in the BAC. As a first attempt to fill this gap, the Basque Government (2017) recently made a study into English proficiency in the BAC. The population of 18 years or older, represented by a sample of 1000 participants in a telephone interview, was studied in terms of their knowledge of foreign languages.

A total of $35 \%$ of the population of the BAC state that they are able to speak and write English; 54\% only speak English; 6\% only read English; and the majority, $55 \%$ of the population, cannot speak, write or read English. These percentages drop significantly when looking at other languages. A total of $80 \%$ of the population has no knowledge of French (the most frequent language after English), and this percentage is $97 \%$ for Portuguese, German and Italian, and even higher for other foreign languages (Basque Government, 2017).

However, the numbers vary according to the age and social class of the population. The younger the population and the higher the social class, the more English they speak. For instance, in the age range 18-29 years old, 78\% can speak and write English, whereas in the age range 65 and older this percentage is only $8 \%$.

However, although these data provide a general idea about the population's knowledge of English in the BAC, they do not tell us so much about the level of proficiency. Therefore, the participants who said they knew English were asked whether they are able to have a fluent conversation in English. In this case, $56 \%$ of the population with a knowledge of English state they can have a fluent conversation in English, while 43\% say they cannot. ${ }^{2}$

It should be pointed out that the use of foreign languages is very limited in this context. Whereas $44 \%$ of the participants stated they did not know any

$21 \%$ of the participants did not answer this question. 
foreign languages and therefore never used any, of the participants who did have a command of foreign languages the majority (23\%) never or almost never used them, $19 \%$ only used them sometimes, $8 \%$ often but not on a daily basis, and $7 \%$ on a daily basis.

\section{Languages in the workplace of the Basque Autonomous Community}

As mentioned above, the workplace is one of the places where the use of both local and global languages merges in response to the needs of both the local and the global market. After leisure (24\%), the workplace (14\%) is the second most important area in which people use the foreign languages they know, before family or friends (10\%) and for study purposes (9\%) (Basque Government, 2017).

The use of foreign languages in the workplace also appears to be a motivation for learning languages (mainly English, but also French and German to a lesser extent). While the most important reason given for using languages is travelling (41\%), people often simply like knowing languages (27\%), and they realize the importance of languages for their career prospects (15\%) and of the importance of English as a global language (11\%) or for purposes of study (2\%). Although only a small percentage of the population is currently studying a foreign language (8\%), mainly English, the main reason for studying is because they need it for professional or study purposes. These data make it clear that although few people are competent in and use foreign languages, and that this competence and use is largely limited to English, they are often motivated by professional purposes.

Regarding the local languages, the picture is somewhat different. First of all, Spanish is prevalent in the workplace, since it is the main default language used in this area. Basque is used in a more limited way. Martinez de Luna (2013) studied the reasons for the use of Basque in the workplace. According to his study, more than half of all uses of Basque are explained by the sociolinguistic context (mainly with friends followed by the family), $35 \%$ by oral competence in Basque, $5 \%$ by age and only $1 \%$ by opinion or attitude. As far as the use of Basque in the workplace is concerned, the Basque Government (2011b) again provides important data. Data from 1,806 telephone interviews with the population of the BAC aged 15 or more revealed the following. Among the professionally active population, the majority of the working population always speaks Spanish (63\%), while only $14 \%$ always speaks Basque, and the rest use both languages to some extent or another (5\% more Basque than Spanish, $8 \%$ as much Basque as Spanish, and 8\% more Spanish than Basque). 
These data appear to be strongly related to the level of oral fluency, as shown in the figure below.
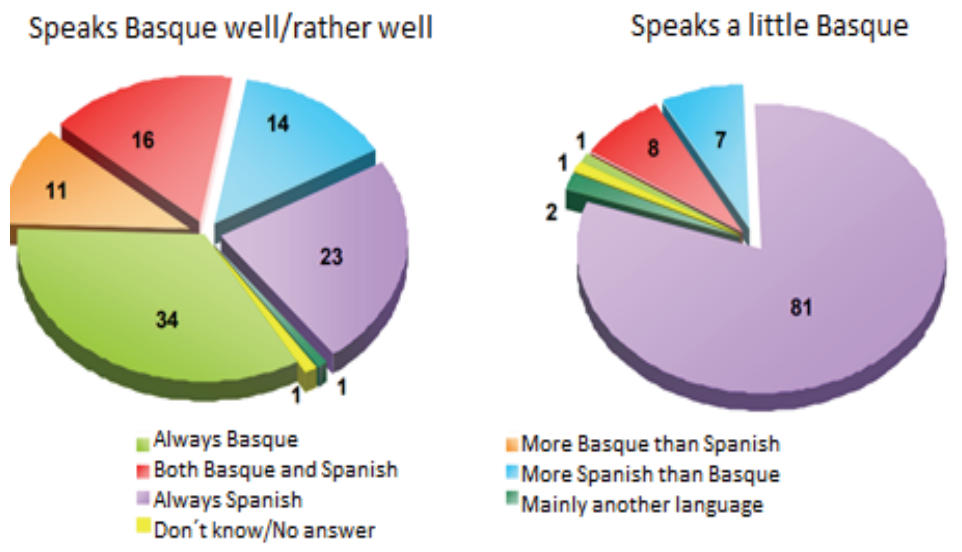

Figure 1: Use of Basque at work according to proficiency in Basque (adapted from: Basque Government, 2011)

The data clearly show that the use of either only Basque or only Spanish is highly influenced by the level of proficiency in Basque. The use of only Spanish is significantly higher in those who only speak a little Basque than in those who speak Basque (rather) well ( $81 \%$ and $23 \%$, respectively), while the use of Basque drops from $34 \%$ to only $1 \%$.

This study uses the data provided in this section about the BAC, companies, and language use and knowledge to shed light on how these languages are perceived by professionals. The analysis focuses on the perceptions of professionals who use several languages in their current jobs, and the perceptions of future professionals who will probably need to use several languages in their future jobs. In the next section, the methodology of the present study will be explained.

\section{Methodology}

The empirical data for this study was acquired using both quantitative and qualitative research tools. On the one hand, the quantitative data provided by future professionals gives an insight into what they expect in terms of languages in their future workplace. On the other hand, working professionals, those who have first-hand experience of multilingualism in their companies, provide more in-depth information on reality by means of interviews. The combination of both methodologies is considered an adequate approach to provide a solid dataset. Both data collection procedures will be explained in this section. 
The quantitative data was obtained from future professionals studying Business Administration at the University of the Basque Country. Paper and pencil questionnaires were used to gather data from 198 students with a mean age of 20.63 years old, with very similar numbers of men $(\mathrm{N}=100)$ and women $(\mathrm{N}=98)$. Students were enrolled in the second year $(\mathrm{N}=116)$ and third year $(\mathrm{N}=82)$ of the degree in Business Studies. The questionnaire consisted of seven parts: i) general background information, ii) language learning experiences and competences, iii) English competences for the workplace, iv) language use in daily life, v) cultural competences, vi) perceptions on languages in the future workplace, and vii) opinions about language use in the workplace. Data were entered into SPSS (Statistical Data Analysis Software) for analysis.

Qualitative data was obtained by face-to face interviews with 25 professionals in managerial positions from 14 different companies, ${ }^{3}$ all located in the Basque Autonomous Community. An overview of the economic sector, the type of company and the job position of the informants is provided in the following table:

\begin{tabular}{|c|c|c|}
\hline Sector & Company & Job position of informant \\
\hline \multirow[t]{5}{*}{ Factories } & Factory of metal parts & $\begin{array}{l}\text { General director } \\
\text { Director of client services } \\
\text { Director of language commission } \\
\text { Human resource manager } \\
\text { Quality manager } \\
\text { Sales manager }\end{array}$ \\
\hline & $\begin{array}{l}\text { Factory of professional } \\
\text { and industrial tools }\end{array}$ & $\begin{array}{l}\text { General director } \\
\text { Export manager Asia } \\
\text { Export manager America } \\
\text { Export manager Middle East } \\
\text { Regional manager }\end{array}$ \\
\hline & $\begin{array}{l}\text { Factory of } \\
\text { automotive components }\end{array}$ & Floor manager \\
\hline & Factory of electronics & Corporate chief technology officer \\
\hline & Factory of adhesive tape & Sales manager \\
\hline \multirow[t]{2}{*}{ Service providers } & Logistics company & Branch manager \\
\hline & IT service company & Marketing director \\
\hline \multirow[t]{3}{*}{ Corporations } & R\&D group & Director of international development \\
\hline & $\begin{array}{l}\text { Association of } \\
\text { Language Industries }\end{array}$ & General Director \\
\hline & Business Group & Director of co-operative dissemination \\
\hline $\begin{array}{l}\text { Language } \\
\text { academy }\end{array}$ & Language academy & Director of communication \\
\hline
\end{tabular}

3 In some companies interviews were held with more than one informant. Due to the way work was distributed in the companies, some informants could only give part of the required information and had to be completed by information from other informants. 


\begin{tabular}{|l|l|l|}
\hline Sector & Company & Job position of informant \\
\hline $\begin{array}{l}\text { Consultancy } \\
\text { firms }\end{array}$ & Basque consultancy & $\begin{array}{l}\text { Innovation and Project manager } \\
\text { Head of consultancy }\end{array}$ \\
\cline { 2 - 3 } & $\begin{array}{l}\text { Internationalization } \\
\text { consultancy }\end{array}$ & General manager \\
\cline { 2 - 3 } & $\begin{array}{l}\text { Internationalization } \\
\text { consultancy }\end{array}$ & $\begin{array}{l}\text { Inside sales manager } \\
\text { International sales consultant }\end{array}$ \\
\hline
\end{tabular}

Table 1: Sector, type of company and job position of the informants

As shown in the table, the companies belong to different sectors: five factories, two service providers, three corporations, one language academy and three consultancy firms. The variety of companies chosen aims to provide a solid sample of the workplace in the BAC from different perspectives. The participants were interviewed using a schedule with open questions, which asked about the professionals and the company, the level of multilingualism of employees, language requirements, cultural differences, language use, language policy and education. Seventeen participants chose to do the interview in Spanish, whereas the remaining eight preferred to do the interview in Basque. The interviews, which lasted between 40 and 105 minutes each, were audio recorded, transcribed and coded using the program Atlas.ti (Qualitative Data Analysis Software). ${ }^{4}$

This paper will discuss only the data from the two sources (interviews and questionnaires) that are relevant to the following research question:

How do professionals and future professionals perceive the local and global languages in the workplace of the Basque Autonomous Community?

We expect to find that the perceptions of future professionals are initially positive towards multilingualism in the workplace, but that the working professionals perceive in that companies will have difficulty in reaching a truly multilingual working environment. The analysis of these perceptions on multilingualism in the workplace could provide valuable information about how professional multilingualism can be improved.

4 All informants were assigned a code for adequate source referencing. The code consists of MP (abbreviation of Multilingual Professional) followed by an underscore and the number assigned to the participant. E.g. [MP_01] 


\section{Results}

This section first presents the data from the future professionals, followed by the data from the professionals.

\section{Perceptions of the future professionals on languages in the workplace}

The majority of the future professionals $(\mathrm{N}=103)$ say they have Spanish as their mother tongue. A total of 78 say that Basque is their mother tongue, 3 consider them both to be their mother tongue and 12 say they have other mother tongues.

When asked to assess their own competences in the languages they know, on a scale from one to ten, the results are as shown in table 2 .

\begin{tabular}{|l|l|l|l|l|l|l|l|l|}
\hline & \multicolumn{2}{|c|}{ Basque } & \multicolumn{2}{c|}{ Spanish } & \multicolumn{3}{c|}{ English } & \multicolumn{2}{c|}{ Other } \\
\hline & $\mathrm{M}$ & $\mathrm{SD}$ & $\mathrm{M}$ & $\mathrm{SD}$ & $\mathrm{M}$ & $\mathrm{SD}$ & $\mathrm{M}$ & $\mathrm{SD}$ \\
\hline Listening & 8.70 & 2.33 & 9.57 & 1.05 & 6.83 & 1.56 & 4.94 & 2.85 \\
\hline Speaking & 7.95 & 2.63 & 9.06 & 1.58 & 5.81 & 1.69 & 4.23 & 2.82 \\
\hline Reading & 8.61 & 2.40 & 9.33 & 1.34 & 6.97 & 1.62 & 4.63 & 2.97 \\
\hline Writing & 8.00 & 2.61 & 8.90 & 1.64 & 6.28 & 1.77 & 3.81 & 2.79 \\
\hline
\end{tabular}

Table 2: Business Students' perceptions of their language competences on a scale from 1 (not at all) to 10 (very good)

These data show that the highest competences are found in Spanish (listening $M=9.57, S D=1.05$; speaking $M=9.06, S D=1.58$; reading $M=9.33$, $\mathrm{SD}=1.34$; and writing $\mathrm{M}=8.90, \mathrm{SD}=1.64)$. This is followed by Basque (listening $\mathrm{M}=8.70, \mathrm{SD}=2.33$; speaking $\mathrm{M}=7.95, \mathrm{SD}=2.63$; reading $\mathrm{M}=8.61, \mathrm{SD}=2.40$; and writing $\mathrm{M}=8.00, \mathrm{SD}=2.61$ ) and then English with a clearly lower score (listening $\mathrm{M}=6.83, \mathrm{SD}=1.56$; speaking $\mathrm{M}=5.81, \mathrm{SD}=6.97$; reading $\mathrm{M}=6.97$, $\mathrm{SD}=1.69$; and writing $\mathrm{M}=6.28, \mathrm{SD}=1.77)$. In other languages, students show that they are far less competent than in English (listening $\mathrm{M}=4.94, \mathrm{SD}=2.85$; speaking $\mathrm{M}=4.23, \mathrm{SD}=2.82$; reading $\mathrm{M}=4.63, \mathrm{SD}=2.97$; and writing $\mathrm{M}=3.81$, $\mathrm{SD}=2.79$ ).

The students were asked to evaluate their competences in English in the context of their future workplace. Therefore, the various linguistic tasks that are carried out in a professional context were presented to the students in order to evaluate their ability to fulfil them. The tasks were of increasing difficulty in terms of the CEFR framework. ${ }^{5}$ The ability of the students to carry out the professional tasks in English at a range of levels from A1 to C2 is shown in table 3:

5 The linguistic difficulty of professional tasks according to the CEFR framework was determined by ALTE (2002). They present CAN DO statements for three groups of skills: listening/speaking, reading and writing. These CAN DO statement are used for this item of the questionnaire. 


\begin{tabular}{|l|l|l|l|l|l|l|l|l|l|l|l|l|}
\hline & A1 & & A2 & & B1 & & B2 & & C1 & & C2 & \\
\hline & M & SD & M & SD & M & SD & M & SD & M & SD & M & SD \\
\hline List./speak. & 8.92 & 1.53 & 8.88 & 5.13 & 6.98 & 1.82 & 7.05 & 1.88 & 5.70 & 2.09 & 4.63 & 2.34 \\
\hline Reading & 8.08 & 1.85 & 7.65 & 1.86 & 6.92 & 1.85 & 6.88 & 1.88 & 5.87 & 2.09 & 5.07 & 2.17 \\
\hline Writing & 8.52 & 1.61 & 8.22 & 1.72 & 7.29 & 1.80 & 6.81 & 1.84 & 6.02 & 2.04 & 5.41 & 2.26 \\
\hline
\end{tabular}

Table 3: Business students' perceptions of their ability to carry out professional tasks in English at CEFR levels A1 to C2, on a scale from 1 (not capable at all) to 10 (completely capable).

The results show that in general the scores decrease as the complexity of the tasks increases. ${ }^{6}$ Whereas the students say they are well equipped to carry out A1 level tasks (listening/speaking $\mathrm{M}=8.92, \mathrm{SD}=1.53$; reading $\mathrm{M}=8.08, \mathrm{SD}=1.85$, writing $=8.52, \mathrm{SD}=1.61$ ), their ability to carry out $\mathrm{C} 2$ level tasks is clearly lower (listening/speaking $\mathrm{M}=4.63, \mathrm{SD}=2.34$; reading $\mathrm{M}=5.07, \mathrm{SD}=2.17$, writing $=5.41, \mathrm{SD}=2.26$ ). The more difficult the professional tasks, the less able students can fulfil these tasks in English.

The students were asked to rank six different languages they might find in their future workplace in order of importance on a scale of 1 (most important) to 6 (least important). The results are shown in table 4 in order of importance:

\begin{tabular}{|l|l|l|}
\hline Importance of language & $M$ & $S D$ \\
\hline English & 1.73 & 0.82 \\
\hline Spanish & 2.32 & 1.24 \\
\hline Basque & 3.76 & 1.95 \\
\hline German & 3.90 & 1.07 \\
\hline French & 4.59 & 1.05 \\
\hline Chinese & 4.65 & 1.37 \\
\hline
\end{tabular}

Table 4: Business students' perceptions of the importance of languages for their future workplace, on a scale of 1 (most important) to 6 (least important).

We can clearly see that English is the language that is most often put in first place $(M=1.73, S D=0.82)$ is followed by Spanish $(M=2.32, S D=1.24)$, and Basque $(\mathrm{M}=3.76, \mathrm{SD}=1.95)$. Other foreign languages are considered to be less important, with the following order of importance: German ( $M=3.90$, $\mathrm{SD}=1.07)$, French $(\mathrm{M}=4.59, \mathrm{SD} 1.05)$ and finally Chinese $(\mathrm{M}=4.65, \mathrm{SD}=1.37)$.

After presenting the quantitative data on the perceptions of the future professionals about their language competences and the importance of languages for their future workplace, we will now turn to the qualitative data that describe the perceptions of the professionals about the languages used in their workplace.

6 The listening/speaking competence on a B1- and B2-level task is the only exception where students consider themselves slightly better able to carry out the $\mathrm{B} 2$ task $(\mathrm{M}=7.05, \mathrm{SD}=1.88)$ than the $\mathrm{B} 1$ task: $(\mathrm{M}=6.98$, $\mathrm{SD}=1.82$ ) 


\section{Perceptions of professionals on languages in the workplace}

The professionals in the company explain that companies usually aim to use the client's language:

Si yo quiero comprar, puedo comprar en el idioma que me dé la gana. Vender, tengo que vender en el idioma del país de destino para ser más efectivo.

[If I want to buy, I can buy in whatever language I want. To sell, I have to use the language of the target country to be more effective.] [MP_11]

However, using the target language is not always possible, because the staff lack certain language skills. Therefore, the main foreign language used in companies is English. For instance, one of the informants [MP_01] mentions that her company uses English to deal with Arabia, Asia, East Africa, Russia and several places in Europe. One professional stated that using English with these countries sometimes causes communication problems, and gives Russia and Poland as examples [MP_08]. A professional from another company [MP_14] agrees that sometimes they cannot attend clients in their language, because they simply do not have the language skills. She explains that if they had a client in Japan, they could not use Japanese, but would have to use English instead. However, as soon as Japan became a large market, they would employ someone with a command of Japanese.

Some countries that prefer not to use English are France [MP_08] and West Africa where French is usually spoken [MP_01] and Germany [MP_08,MP_01]. In Italy, English or Spanish is normally used [MP_01] and in Portugal it is most likely that communication is in Spanish [MP_04]. Even in Romania, although the initial intention would be to use English with the clients, communication is often smoother in Spanish [MP_01].

It is interesting to point out that even the use of Spanish, which is spoken in many parts of Latin America as well as in Spain, can cause trouble on the international market. It seems that Spanish from Spain and Spanish from Latin America have different nuances that should be taken into account when "translating" from one variety to the other:

Las ofertas que preparamos las tenemos que traducir al mexicano, que el español no es igual que el mexicano. Suena extraño leer ahí algo hecho aquí, con lo que sí tenemos una tarea de traducción adicional. Es el mismo idioma, pero los usos y matices son distintos y suena raro. Tenemos personas locales que precisamente adecuan la oferta al sabor local. [MP_04] 
[We have to translate our offers into Mexican, because Spanish is not the same as Mexican. Reading there something written here sounds strange, and therefore we do have an extra translation task. It is the same language, but the uses and nuances are different and it sounds strange. We have local people who precisely adapt the offer to the local taste.] [MP_04]

In general, the foreign languages most used in companies are English, followed by French and German. Other languages such as Italian, Portuguese, Russian and Chinese are also occasionally found.

Because of the need for several languages in the workplace, some companies have decided to set foreign language knowledge as a requirement for employing new staff. However, foreign language requirements differ slightly between companies. Some companies already take English for granted and set English plus another foreign language as a prerequisite [MP_01, MP_08, MP_03]. One of the informants explains:

Yo si tuviera que incorporar gente nueva en mi equipo es un requisito imprescindible. El inglés por supuesto, y creo que todo el mundo lo da por hecho. No viene a sumar. [MP_08]

[If I had to contract new people for my team it is a necessary requirement. English for sure, I think that everybody takes that for granted. It does not count extra.][MP_08]

Other companies have set only English as a foreign-language requirement [MP_05, MP_012, MP_07].

However, the requirement of English is not always the same. For some positions, English is more necessary than for others. For instance, if employees have to work on international projects [MP_05], or in general occupy intermediate positions [MP_16], English is considered a must. In other job positions, such as factory floor workers, English is usually considered less important.

According to informant [MP_06], an added difficulty with language requirements is that companies are not clear about exactly what linguistic competences are needed. Usually they do understand exactly what technical or professional competencies are needed, but they do not have the same understanding of languages.

There are differences in the competences required by different companies. In general, the level of English is not perceived to be very high [MP_01]. Exceptions are the companies that work on international research projects [MP_05]. Some companies state that they cope with reading documentation in English very well [MP_04], [MP_07]. Other companies say they manage daily professional tasks 
rather well [MP_16], [MP_12], [MP_07]. In contrast, more difficult tasks such as "presenting an offer to the World Bank", is a serious problem [MP_04]. What is underlined is that the employees who really need English skills for external contacts are well prepared. Employees in lower positions are usually less well prepared.

Most informants said they were not satisfied with the results of education in terms of foreign language acquisition [MP_01], [MP_03], [MP_08], [MP_09], [MP_13], [MP_06], [MP_12]. Another informant, however, believes that it is not so much education but a cultural issue; they do not understand the need to learn languages [MP_16].

The majority language, Spanish, is perceived as the default language in all companies except one [MP_14], where they use more Basque than Spanish in response to a well-defined language strategy for the promotion of Basque in their workplace. In most companies, Spanish is mainly used as the formal language of work, whereas Basque is more limited to informal communication among colleagues, and for communication with local clients who prefer to speak Basque.

Unlike English, which is usually set as a minimal requirement in companies, Basque is perceived more as an asset [MP_04], [MP_07] than as a requirement [MP_01]. Again, as with English, the need for Basque also depends on the job position. If an employee has to work on local projects, knowing Basque is more important [MP_05].

There is considerable concern about the results of language education not only for English but also for the local language Basque because, despite the efforts in education, there is still a high ratio of people who do not speak Basque [MP_09].

Now that the quantitative data concerning the professional students and the qualitative data concerning the professionals have been presented, we shall now move on to discuss how our results respond to our research question.

\section{Discussion and conclusion}

This study aims to shed light on the perceptions of both professionals and future professionals about languages in the workplace of the Basque Autonomous Community (BAC). We have presented the basic notions on the theoretical framework from which we consider multilingualism at work in this study and explained the sociolinguistic context of the BAC. It is clear that both the knowledge and use of a local minority and majority language and the increasing knowledge and use of a global language merge in a situation of "glocal" multilingualism in the Basque society, and especially in the workplace. The research question we have sought to answer is: 
How do professionals and future professionals perceive the local and global languages in the workplace of the Basque Autonomous Community?

Data for answering this research were collected by means of a mixed methodology. On the one hand, quantitative data were gathered by administering questionnaires to Business students to find out more about the perceptions of future professionals on languages in the workplace. On the other hand, qualitative data were gathered from professionals working in internationally operating companies in the BAC, by means of interviews.

The results of the self-evaluation of language competences by the future professionals show that they are not equally competent in all languages or all skills. Spanish is the language the future professionals are most competent in, followed by Basque and English, respectively. It is clear from the data that skills in foreign languages other than English are generally low. In general, competences were perceived to be lower for speaking and writing than for reading and listening. This supports the holistic point of view of "Focus on Multilingualism" which assumes that multilingual speakers have fluid competences in several languages, which are not comparable to the sum of competences of native monolingual speakers (Cenoz and Gorter, 2011a, 2011b, 2014).

The data about the language competences of future professionals are corroborated by the data provided by the professionals. Spanish is perceived as the default language in the workplace, the language all employees are highly fluent in. This is in line with the data from the Basque Government (2017) which showed that $63 \%$ of the working population said they always use Spanish at work. Informants explained that not all employees speak Basque. Data from the Basque Government (2016) also showed that little more than a third of the population 16 years and older speaks Basque. Use of Basque in the workplace is therefore often limited to informal communication at work or specific communication with local clients or institutions who require the Basque language to be used. Here we see how the linguistic context directly influences professional discourse (Gunnarsson, 2009, 2013 \& 2014).

Although companies aim to use the language of their foreign clients, in general English is the language used for foreign markets. Staff members have different competences in English, depending on the job position. Professionals admit that employees who need to use English can deal with daily tasks but that more difficult tasks, such as contracts and offers, can cause problems. The future professionals confirmed this, as they consider themselves clearly less capable of carrying out high-level professional tasks in English than basic-level tasks. This 
variety of linguistic tasks advocates for considering the whole linguistic repertoire of the professionals (van der Worp et alii, 2017).

Nowadays, English is usually set as a requirement for new employees. Companies ask for either English only, or English plus an additional foreign language. However, the professionals interviewed generally feel that education does not provide students with sufficient language skills in English. This confirms that education is indeed an influencing factor on the professional discourse (Gunnarsson, 2009, $2013 \& 2014$ ). This idea is also visible in the data provided by the students, who say that English language skills lie behind the two local language skills, and skills in additional foreign languages are even less well developed. These data coincide with data from the Basque Government (2017), which states that only $35 \%$ of the population is capable of speaking and writing in English, and that over $80 \%$ of the population does not know any other foreign language.

It can clearly be seen that "glocalisation" (Robertson, 1992) is present in the BAC. From the data that the future professionals provided it is clear that they perceive English as the most important language in their future workplace. English is followed by Spanish and, in third place, we find Basque. It is interesting to see that the global language is now considered more important than the local majority and minority language. This might be because companies mainly set English as a requirement for new employees, whereas Spanish is taken for granted and Basque is mainly seen as a mere asset.

To conclude, we can see that professionals and future professionals perceive English, the global language, to be extremely important in the Basque workplace nowadays. However, linguistic skills in English still need to be improved if staff are to successfully complete the more demanding high-level professional tasks. In addition, other foreign languages should be given greater importance so that foreign clients can be attended in their own language. This is one of the main aims of companies but one that they do not usually manage to achieve. Whereas Spanish is taken for granted as a default working language, perceptions of Basque are rather different. Basque is often regarded as an asset, a language for informal communication in the workplace or for specific communication with local clients.

On the basis of these conclusions, some recommendations could be made for improving the multilingual situation in the workplace. First, higher education should pay more attention to English language acquisition to prepare the students linguistically for the specific professional tasks of their future jobs. Furthermore, additional in-company training could also be helpful to prepare professionals linguistically once they are at work. Second, the fact that English 
is the main foreign language in education and in-company training should be revised, and opportunities for including additional foreign languages in the curriculum should also be explored. Lastly, language policies focusing on Basque in the workplace still very much seem to be needed to reinforce the position of this language in the workplace.

Future research could shed more light on how to find an adequate balance among the languages in the workplace of the Basque Autonomous Community in terms of competences, use and importance.

\section{References}

Alarcón, Amado (2005). "Movilidad de los factores, eficiencia y discriminación lingüística: Análisis de cuatro escenarios empresariales en Cataluña”. Revista De Sociolingüistica, 2. Retrieved from <http://www.gencat.cat/llengua/ noves/noves/hm05hivern/docs/alarcon.pdf $>$.

ALTE (2002). The ALTE Can Do project: Articles and Can Do statements produced by the members of ALTE 1992-2002. Retrieved from <http://www. cambridgeenglish.org/images/28906-alte-can-do-document.pdf $>$.

Basque Consortium (2016). Guía de programas y servicios para la internacionalización de las empresas vascas 2016. Accessed 27/09/2018: <http://www. industria.ejgv.euskadi.eus/contenidos/informacion/presentacion_intern/ es_intern/adjuntos/guia_basque_comsorcium_es.pdf >.

Basque Government (2011a). V Encuesta Sociolingüistica País Vasco, Comunidad Autónoma Vasca, Navarra, País Vasco Norte. 2011. Accessed 02/10/2018: $<$ http://www.euskara.euskadi.eus/contenidos/informacion/argitalpenak/ es_6092/adjuntos/VEncuesta.pdf > .

Basque Government (2011b). Euskera: uso, actitudes, politicas. Accessed 02/10/2018: <http://www.euskadi.eus/contenidos/documentacion/ o_10tef3_euskera/es_10tef3/adjuntos/10tef3_euskera_es.pdf $>$.

Basque Government (2015). Política de Internacionalización. Accessed 27/09/2018: <http://www.industria.ejgv,euskadi.eus/r44-de0017/es/contenidos/informacion/presentacion_intern/es_intern/pol_inter.html $>$.

Basque Government (2016)."VI Encuesta Sociolingüística Comunidad Autónoma de Euskadi". Accessed 02/10/2017: <http://www.euskadi.eus/contenidos/informacion/argitalpenak/es_6092/adjuntos/Resumen_VI_Encuesta_Socioling\%C3\%BC\%C3\%ADstica_EAE_\%202016_1.pdf >.

Basque Government (2017). Atzerriko bizkuntzen ezagupena eta ikasketa - Conocimiento y aprendizaje de idiomas extranjeros. Accessed 02/10/2018: 
<https://www.irekia.euskadi.eus/uploads/attachments/9475/Estudio. pdf?1493809302>.

Cenoz, Jasone \& Gorter, Durk (2011a). "A holistic approach in multilingual education: Introduction". The Modern Language Journal, 95(3), 339-343. doi: $10.1111 / \mathrm{j} \cdot 1540-4781.2011 .01204 \times \times 273$

Cenoz, Jasone \& Gorter, Durk (2011b). "Focus on multilingualism: A study of trilingual writing". The Modern Language Journal, 95(3), 356-369. doi:10.1111/j.1540-4781.2011.01206.x

Cenoz, Jasone \& Gorter, Durk. (2012). "Hacia un horizonte multilingüe”. In E. Alcón, \& F. Michavila (Eds.), La Universidad Multilingüe (pp. 131149). Madrid: Editorial Tecnos.

Cenoz, Jasone \& Gorter, Durk (2014). "Focus on multilingualism as an approach in educational contexts". In A. Creese, \& A. Blackledge (Eds.), Heteroglossia as practice and pedagogy (pp. 239-254). Berlin: Springer.

Day, Dennis \& Wagner, Johannes (2007). "Bilingual professionals". In P. Auer, \& L. WeI (Eds.), Handbook of multilingualism and multilingual communication (pp. 391-404). Berlin: Mouton de Gruyter.

Edwards, John (1995). Multilingualism. England: Penguin Books.

EF (2017). Indice del EF English Proficiency. Accessed 03/10/2018: <https:// www.ef.com.es/epi/regions/europe/>.

European Commission (2007). Commission of the European Communities High Level Group on Multilingualism. FINAL REPORT. Retrieved from $<$ http://bookshop,europa,eu/en/high-level-group-on-multilingualism-

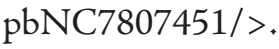

EUSTAT (2017a). Población de la C.A. de Euskadi por año de nacimiento, según el territorio bistórico y el sexo. 01/01/2017. Accessed 27/09/2018: <http://www. eustat.eus/elementos/ele0011400/Poblacion_de_la_CA_de_Euskadi_por_ ano_de_nacimiento_segun_el_territorio_historico_y_el_sexo/tbl0011424_c. html $>$.

EUSTAT (2017b). Ranking de las exportaciones de la C.A. de Euskadi por paises (miles de euros). Accessed 27/09/2018: <http://www.eustat.eus/elementos/ ele0005700/Ranking_de_las_exportaciones_de_la_CA_de_Euskadi_por_ paises_miles_de_euros_p/tbl0005722_c.html >.

EUSTAT (2017c). Ranking de las importaciones de la C.A. de Euskadi por países (miles de euros). Accessed 27/09/2018: <http://www.eustat.eus/elementos/ ele0005700/Ranking_de_las_importaciones_de_la_CA_de_Euskadi_por_ paises_miles_de_euros_p/tbl0005723_c.html> 
EUSTAT (2018). Euskal Urtekari Estatistikoa. Anuario Estadistico Vasco. Accessed 27/09/2018: <http://www.eustat.eus/document/epubs/publicaciones/ anuario2018_c/offline/download.pdf $>$

Franceschini, Rita (2009). "The genesis and development of research in multilingualism. Perspectives for future research". In L. Aronin, \& B. Hufeisen (Eds.), The Exploration of Multilingualism: Development of research on L3. Multilingualism and multiple language acquisition (pp. 27-61). Amsterdam / Philadelphia: John Benjamins Publishing Company.

Gunnarsson, Britt-Louise (2009). Professional discourse. Londonः Continuum Discourse Series.

Gunnarsson, Britt-Louise. (2013). Multilingualism in the workplace. Annual Review of Applied Linguistics, 33,162-189. doi:10.1017/S0267190513000123

Gunnarsson, Britt-Louise (2014). "Multilingualism in European workplaces". Multilingua-Journal of Cross-Cultural and Interlanguage Communication, 33(12), 11-33. doi $10.1515 /$ multi-2014-0002

Kemp, Charlotte (2009). Defining multilingualism. In L. Aronin. \& B. Hufeisen (Eds.), The exploration of multilingualism. Development of research on L3. Multilingualism and multiple language acquisition (pp. 11-26). Amsterdam/Philadelphia: John Benjamins Publishing Company.

Martinez de Luna, Iñaki (2013). El euskera en la CAPV: competencia, uso y opinión. Análisis y reflexiones. Accessed 02/10/2018: <http*//www.euskadi. eus/contenidos/informacion/ikerketa_soziolinguistikoak/eu_def/adjuntos/El\%20euskera\%20en\%20la\%20CAPV.pdf>.

Robertson, Roland (1992). Globalization: Social Theory and Global Culture. London: Sage.

Solé, Carlota; Alarcón, Amado; Terrones, Albert, \& Garzón, Luis (2005). "Eficiencia y discriminación lingüística en la empresa". Revista Española de Investigaciones Sociológicas, 11-35. Retrieved from <http»//www.jstor.org/ stable/40184666?seq=1\#page_scan_tab_contents $>$.

Van der Worp, Karin; Cenoz, Jasone \& Gorter, Durk (2017). "From bilingualism to multilingualism in the workplace: The case of the Basque Autonomous Community". Language Policy 16(4), 407-432. doi¥10.1007/ s10993-016-9412-4. 